University of Nebraska - Lincoln

DigitalCommons@University of Nebraska - Lincoln

September 1986

Interference competition in a heteromyid community in the Great Basin of Nevada, USA

Cliff A. Lemen

University of Nebraska-Lincoln, clemen2@unl.edu

Patricia W. Freeman

University of Nebraska-Lincoln, pfreeman1@unl.edu

Follow this and additional works at: https://digitalcommons.unl.edu/natrespapers

Part of the Natural Resources and Conservation Commons

Lemen, Cliff A. and Freeman, Patricia W., "Interference competition in a heteromyid community in the Great Basin of Nevada, USA" (1986). Papers in Natural Resources. 14.

https://digitalcommons.unl.edu/natrespapers/14

This Article is brought to you for free and open access by the Natural Resources, School of at DigitalCommons@University of Nebraska - Lincoln. It has been accepted for inclusion in Papers in Natural Resources by an authorized administrator of DigitalCommons@University of Nebraska - Lincoln. 


\title{
Interference competition in a heteromyid community in the Great Basin of Nevada, USA
}

\author{
Cliff A. Lemen and Patricia W. Freeman
}

Lemen, C. A. and Freeman, P. W. 1986. Interference competition in a heteromyid community in the Great Basin of Nevada, USA. - Oikos 46:3, pp. 390-396.

Removal experiments with three species of heteromyid rodents were performed during two summers in the Great Basin of Nevada, USA. These experiments were designed to determine the importance of interference competition in these species by quantifying the short-term responses to the removal of one or more of the species. Our results indicate that the removal of a large species (Dipodomys merriami) does have a positive effect on a smaller species with a similar diet (Perognathus longimembris). These results and others presented are consistent with a hypothesis of interference competition. However, while there is short-term increase in number of rodents in response to removals, the increase is not commensurate with the number of animals removed. We conclude that interference competition was present but weak in the two summers we manipulated this community.

Cliff A. Lemen and Patricia W., Freeman, School of Biological Sciences and University of Nebraska State Museum, University of Nebraska-Lincoln, Lincoln, NE 68588, USA.

\begin{abstract}
Проводились опы по изъятию на трех видах грызунов Heteromyidae в течение двух летних сезонов в Болышам Бассейне Невалы, СІА. Эти эксперименты поставлены для опеределения значения интерференции в конкурентных отнашениях этих видов путем количественной оценки кратковременных реакий на удаление отюго или более видов. Нани результаты показали, что изъятие крупного вида $D i-$ podomys mетriсmi оказывает положительный эффект на более мелкие виды с такими же питевыми потребностями - Perognathus Longimembris. Эти и другие представленные результаты поддерживают гипотезу интепференционной конкуренции. Однако, наряду с кратковременным повышением численности грызунов в ответ на изъятие, это увеличение несоизмеримо с числам изъятых животных. Мы принти к заключению, что интерференционная конкуренция имела место, но бы ла более слабой в те два летние сезона, когда ставились опыы на популяци.
\end{abstract}

Published by Blackwell Publishing for the Nordic Ecological Society. Used by permission. "The definitive version is available at http://blackwell-synergy.com" 


\section{Introduction}

Communities of desert rodents are one of the principal systems that have been used by community ecologists to elucidate and test their ideas. The quantification of competition has been one of the main foci of work on these systems. Many of the earlier works emphasized resource partitioning and exploitative competition by quantification of differences in resource use. The first resources studied for partitioning were microhabitats and seed sizes (Rosenzweig and Winakur 1969, Brown 1975). Later seed size was abandoned as a partitioned resource (Smigel and Rosenzweig 1974, Lemen 1978, Stamp and Ohmart 1978) and seed distribution (clumped vs scattered) proposed (Reichman and Oberstein 1977, Hutto 1978, Reichman 1981). The role these factors play in reducing competition and ultimately allowing coexistence is still unclear. The difficulty arises because of the inherently circumstantial evidence generated by these studies.

Munger and Brown (1981) used an experimental approach to assess competition by removing one species of rodent and quantifying the effect on another species. They found that the remaining species did react, but only after several months had passed. This slow reaction time is consistent with exploitative competition; there is no response until resource levels change. Likewise, Schroder and Rosenzweig (1975) also found no quick reaction in response to the removal of heteromyids. Thus these experimental studies helped substantiate and solidify the view that competition was exploitative in heteromyid communities. Much of the community level work since Munger and Brown (1981) has continued to center on the exact mechanism of the exploitative interaction with emphasis on the relevance of seed distributions and foraging strategies of different body types (Price 1983, 1984) or the interaction of habitat preferences and predator avoidance (Kotler 1984).

On the other hand it has been suggested (Lemen and Freeman 1983, Frye 1983, Rebar and Conley 1983) that interference competition may be present in heteromyid communities in the desert southwest. Interference competition among heteromyids seems likely for several reasons. First, heteromyids are extremely aggressive both intra- and interspecifically (Eisenberg 1963, Blaustein and Risser 1974, 1976, Congdon 1974, Fleming 1974), and this aggression may lead to hyperdispersion intraand interspecifically (Fleming 1974, Schroder and Geluso 1975, O'Farrell 1980, Frye 1983). Second, there is often a tendency for heteromyid communities to show a regular pattern of body weight differences among coexisting species (Brown 1975, Bowers and Brown 1982). Third, interference competition is a reasonable hypothesis because it has been found in several other rodent communities (Cameron 1971, Brown 1971, Grant 1972). And lastly, when a species of heteromyid is removed from an area, the numbers of that species can recover in as little as a week or two (Schroder and Rosenzweig 1975, Small and
Verts 1983). This rapid adjustment suggests a direct behavioral response to the removal, rather than a response to changes in resource levels. If such a response is possible intraspecifically, it is reasonable to look for a similar response by competitor species.

Removal experiments can be performed to determine if the population of one species is influenced directly by populations of another. If, within a few days or weeks, there is an increase in the density of the remaining species, it is likely that these species are responding directly to the removal of individuals. Slower reactions may indicate a response to changes in resource levels resulting from the removal of a competitor.

Lemen and Freeman (1983) argued that aggressive interactions are important if the removal of a larger species has a positive effect on smaller species, but removal of a small species has no effect on the large one. In a mesquite-blowout habitat in southern New Mexico this prediction of the dominance hierarchy hypothesis was confirmed (Lemen and Freeman 1983). The removal of the large heteromyid Dipodomys (kangaroo rats) stimulated an increase in the smaller Perognathus (pocket mice) in only two weeks, but removal of Perognathus had no effect on Dipodomys. Frye (1983) found that the presence of the large D. spectabilis reduced the use of an area by the much smaller D. merriami. OTarrell (1980) also concluded that there was a dominance hierarchy in a heteromyid community by analyzing spatial distributions. He found that species were often hyperdispersed both intra- and interspecifically. Further, he found that the larger heteromyids were more specialized in habitat requirements than the smaller forms, and that smaller species avoided overlap of home ranges with the larger species. This avoidance is consistent with dominance hierarchy hypothesis that predicts larger species occupy their preferred habitats and eliminate smaller forms.

To obtain more information on the importance of interference competition we conducted a large experiment near Goldfield, Nevada, to remove single species and pairs of species of heteromyids from large unfenced grids. We found the expected shifts in rodent numbers that substantiates the presences of interference competition. However, we also found that species did not enjoy a large short-term increase in response to the removal of a presumed competitor. Indeed, there was little response in spite of the fact that large numbers of rodents were removed from the grids.

\section{Materials and methods}

During the summers of 1980 and 1981 trapping grids were established in the Great Basin desert near Goldfield, Nevada. In the first year 10 grids were used and in the second, 13 grids. Each grid was a $210 \mathrm{~m}$ square (4.4 ha) with trap stations at $15 \mathrm{~m}$ intervals, for a total of 225 trap stations per grid. Sherman live traps $(7.5 \times 23 \mathrm{~cm})$, baited with mixed bird seed, were used. In 1980 the grids 
were trapped from 6 June to 18 August and in 1981 the trapping period ran from 2 June to 8 July. During these periods we trapped for a total of 36,000 trap nights.

The grids were divided up into controls and treatment plots. On the control grids there were no removals, but the grid was trapped at the same intervals as the other grids. In each year two grids were used as controls. There were four experimental treatments: removal of $D$. microps, removal of D. merriami, removal of both these Dipodomys, and removal of $P$. longimembris. All of these treatments were replicated twice the first summer and at least twice the second summer (Figs 1,2).

Initially all grids were censused with two nights of trapping and estimates of the initial number of animals on the grids were obtained using the Jolly method (White 1971). Each animal captured was identified, sexed, weighed, and given a unique eartag (monel fin-gerling tag). On the control grids animals were released. On the second morning of the initial census the animals to be removed were released not on the grid but about eight kilometers away. No animal released in such a manner ever returned to a grid. At about seven day intervals each grid was trapped again to maintain the removals. These periodic trappings also supplied information on the numbers of individuals present for the species that were not being removed.

Of course, the mark-recapture method of censusing cannot be used for a species when all individuals are being removed (recaptures are impossible). Estimates of the number of individuals of a species being removed that were still on a grid were found by using the average percentage of the total animals caught each night. These percentages were calculated by finding the average percentage of animals caught every night on the control grids (based on the estimated total generated by the Jolly index). The values were $85 \%$ for $P$. longimembris, $89 \%$ for $D$. merriami, and $83 \%$ for D. microps. Therefore, on the average $89 \%$ of the $D$. merriami estimated to be on a grid by the Jolly mark-recapture method were caught each night we trapped. Thus, if $30 \mathrm{D}$. merriami were captured on one night on a removal grid we estimated that $33.7 \mathrm{D}$. merriami were actually on the grid (30 is $89 \%$ of 33.7 ).

The study area is located at an elevation of $1530 \mathrm{~m}$ in the Tonopah section of Cronquist et al. (1972). The rainfall averages $11.5 \mathrm{~cm}$ per year. The vegetation is dominated by shadscale (Atriplex confertifolia). Other common bushes included A. canescens, Sarcobatus vermiculatus, Kochia americana, and Lycium cooperi. As is typical of this area the cover of forbs and grasses is relatively low. The entire area is grazed by cattle and feral horses.

The food habits of the common species of rodents were determined by analysis of fecal pellets. During the first year samples were collected from rodents on all grids. Also collected were potential food items to use for reference. Microscope slides were prepared and per- cent diets estimated by the percent coverage of diffent food items in six random microscope fields of view at 50 power (Tab. 1).

Tab. 1. The diets of the common heteromyids are shown as a percentage of the total. These data are from the analysis off fecal samples from all grids during the first summer. Also shown are the dietary overlaps between the species.

\begin{tabular}{|c|c|c|c|c|c|}
\hline \multirow[t]{2}{*}{ Food item } & \multicolumn{5}{|c|}{ Rodent } \\
\hline & P. $l$ & D. $m$ & D. $m i$ & D. $d$ & M. $p$ \\
\hline $\begin{array}{l}\text { Atriplex } \\
\quad \text { (seed) }\end{array}$ & 83.0 & 58.3 & 2.3 & 20.0 & 48.8 \\
\hline Leaf material & 0.2 & 4.6 & 77.2 & 51.1 & 0.0 \\
\hline $\begin{array}{l}\text { Sphaeralcea } \\
\text { (pollen) }\end{array}$ & 0.2 & 3.9 & 6.1 & 1.0 & 0.81 \\
\hline $\begin{array}{l}\text { Sphaeralcea } \\
\text { (seed) }\end{array}$ & 2.2 & 8.3 & 7.1 & 0.0 & 13.4; \\
\hline $\begin{array}{l}\text { Sarcobatus } \\
\quad \text { (seed) }\end{array}$ & 1.4 & 4.2 & 6.8 & 5.7 & 0.0 \\
\hline $\begin{array}{l}\text { Lycium cooperi } \\
\text { (seed) }\end{array}$ & 6.5 & 4.2 & 0.0 & 0.0 & 0.0 \\
\hline $\begin{array}{l}\text { Oryzopsis hymenoides } \\
\text { (seed) }\end{array}$ & 2.9 & 1.8 & 0.6 & 9.0 & 6.8 \\
\hline Insect material & 2.9 & 17.8 & 0.0 & 5.2 & 29.2 \\
\hline \multirow[t]{3}{*}{ Sample size } & 25 & 24 & 20 & 6 & 6 \\
\hline & \multicolumn{5}{|c|}{ Dietary overlaps } \\
\hline & P. $l$ & D. $m$ & D. $m i$ & D. $d$ & M. $p$ \\
\hline P. longimembris & 1.0 & & & & \\
\hline D. merriami & 0.66 & 1.0 & & & \\
\hline D. microps & 0.05 & 0.24 & 1.0 & & \\
\hline D. deserti & 0.26 & 0.36 & 0.61 & 1.0 & \\
\hline M. pallidus & 0.56 & 0.78 & 0.11 & 0.27 & 1.0 \\
\hline
\end{tabular}

\section{Results}

\section{Efficacy of removals}

Removal of rodents from the grids was simple and effective. Each night a large proportion (about $85 \%$ ) of the rodents on a grid were captured. The effectiveness of the removals to reduce the density of a species was tested by comparing the number of animals caught after two weeks of removals with the number caught during the original census on both the control and removal grids. We used the GLM program from the SAS statistical package (general linear models program described in Goodnight et al. 1982). The number of animals caught at two weeks was the dependent factor and the independent factors were: the species, the number captured in the first two day census and the treatment of removal or control. This analysis indicated that a significant amount of the variation in the number of captures at two weeks was explained by number caught in the first census $(\mathrm{F}=35.25, \mathrm{p}<0.0001)$ and by the removal/control treatment $(\mathrm{F}=38.25, \mathrm{p}<0.0001)$. However, species had no effect $(F=0.34, p>0.1)$. Aver- 
aging over all species we find that the removal treatment caused a $71 \%$ decrease in the numbers of individuals caught as compared to the control grids. These findings strongly indicate that the removals successfully decreased the numbers of animals on grids (Figs 1,2).

\section{Removals}

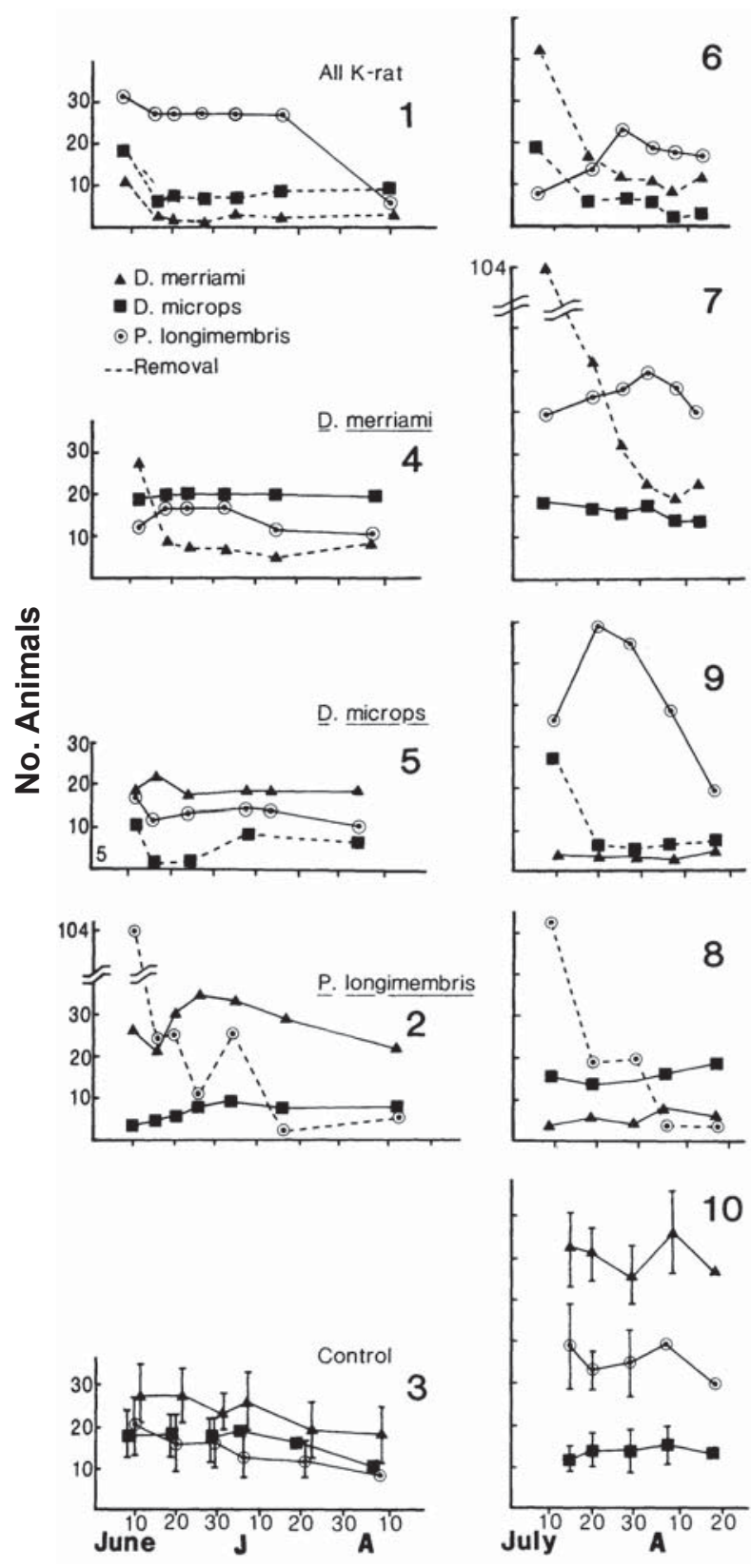

Fig. 1. The number of individuals of the three most common heteromyids as shown for 1980. The dotted lines indicate the species being removed. Each grid and its treatment is listed. There are two grids per treatment with the starting month listed at the left.

\section{Intraspecific effects of removals}

A comparison was made between the rates of arrival of new individuals on the removal and control grids to determine if the removal of a species had an effect on the arrival rate of new individuals of that species. Once again the GLM program was used; the number of new individuals arriving after the initial removal was the dependent variable and the independent variables were: the species, the number of individuals in the first census, and the removal or control treatment. This analysis indicated that the particular kind of species being removed had no effect $(\mathrm{F}=0.01, \mathrm{p}>0.1)$, but that initial numbers $(F=67.5, p<0.0001)$ and removal/control treatment $(\mathrm{F}=10.35, \mathrm{p}<0.01)$ both had significant effects. The rate of arrival of new individuals was $2.74 \%$ per day on removal grids and $1.16 \%$ on the control grids. Schroder and Rosenzweig (1975) found a recovery rate of $5.5 \%$ for Dipodomys in New Mexico and Abramski and Sellah (1982) found a rate of about 3.0\% (short-term) for Gerbillus in Israel.

\section{Interspecific effects of removals}

The effect that removing one species had on other species was analyzed separately for each summer. The numbers of animals on a grid were estimated using the Jolly index and, because standard errors were also generated, any change in estimated numbers on a grid could be tested for significance based on an overlap of two standard errors. By this criterion, there was never a significant increase in numbers for any species on the control grids.

To detect possible effects of the removal of Dipodomys on the numbers of $P$. longimembris a GLM analysis was performed on the data collected during the first summer. The change in rodent numbers after three weeks was the dependent variable and the number of $D$. merriami and $D$. microps removed from the grid were the independent variables. The result of this analysis indicated that removal of $D$. microps had no effect, but the removal of $D$. merriami had a significant and positive effect $(\mathrm{F}=10.7, \mathrm{p}<$ $0.02)$. The slope of this relationship is 0.078 , indicating that for every $13 \mathrm{D}$. merriami removed from a grid there was an increase of one $P$. longimembris. Further analysis indicated no significant effect of the removal of Dipodomys on other Dipodomys, and no significant effect of removal of $P$. longimembris on either Dipodomys.

The analysis just presented used the changes in rodent number at three weeks as the dependent factor because we were interested in the short-term reactions of populations. During the summer of 1980 the removals were maintained for about $60 \mathrm{~d}$ on grids 1 through 5 and for about $35 \mathrm{~d}$ on grids 6 through 10 (Figs 1,2). The reactions of the populations at these longer time periods were no greater than at three weeks.

In the second summer, removals had no detectable effects on the numbers of the rest of the species on a grid 
after two weeks of removals. During the second summer there were considerably fewer individuals of all species on the grids. Based on our simultaneous trapping over a $50 \mathrm{~km}^{2}$ area, we feel this general decline was not due to our removals of the previous year, indeed the decline in the density of rodents was suffered on grids that were controls as well as those from which species were removed.

The analysis of the fecal pellets indicated that there are two basic types of diets in these heteromyids. One group (D. merriami, P. longimembris, and Microdipo-dops pallidus) eats a wide variety of materials including vegetation, seeds and insects. The other group $(D$. deserti and D. microps) concentrates on leaf material. The overlap values of these diets are shown in Tab. 1.

\section{Discussion}

Two factors that would contribute to the evolution of interference competition between species are particularly relevant to this discussion. First, the species would have to be competing for some resource and second, one species would have to be able to dominate the other behaviorally to the extent that it could lessen the competitive impact of the other species. Satisfaction of these two criteria is probably necessary but not sufficient for the evolution of interference competition. Using these two criteria, one can predict where interference competitition would be most likely in the heteromyid community under study. Perognathus longimembris because of its small size would be unlikely to dominate either $D$. merriami or D. microps. D. microps is the largest of the heteteromy-

\section{Removals}

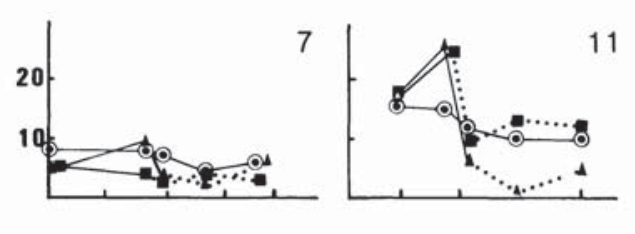

1

All K-rat
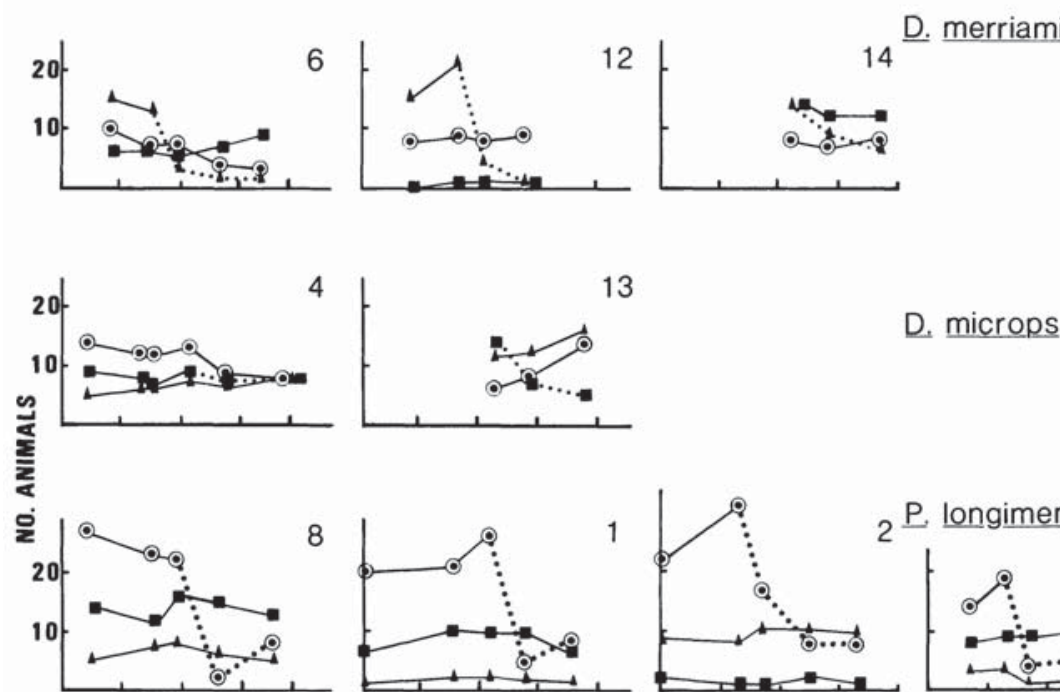

13

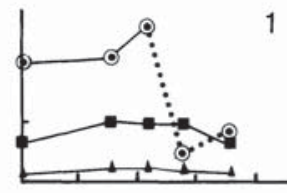

1

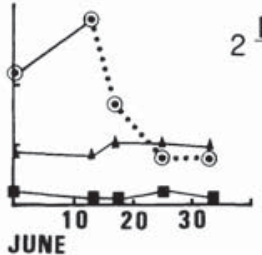

D. microps
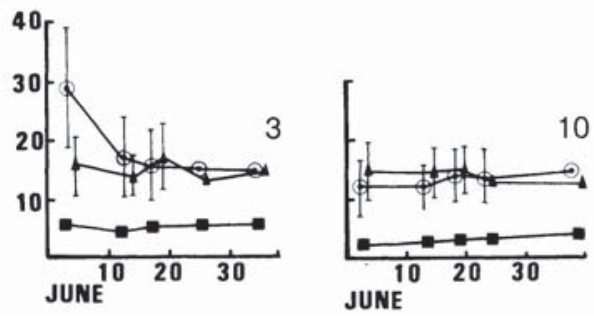

Control

Fig. 2. The number of individuals of the three most common heteromyids as shown for 1981. The dotted lines indicate the species being removed, and the symbols are the same as in Fig. 1. Here there are more than two grids per treatment for D. merriami and P. longimembris 
ids experimentally removed, however, its diet is very different from that of $P$. longimembris and $D$. merriami. If competition for food is the important resource axis then D. microps would not be expected to bother with interfering with the two smaller heteromyids. The last species, $D$. merriami, is smaller than D. microps and has a different diet. Dipodomys merriami is larger than and has a similar diet to $P$. longimembris. Based on this line of reasoning the most likely place to find interference competition in this community is between $D$. merriami and $P$. longimembris.

Just as predicted, our experiments indicate that the emoval of $D$. merriami has a positive effect on the lumbers of $P$. longimembris on grids (at least during the summer of 1980). The removal of $D$. merriami has no measurable effect on $D$. microps and likewise the removal of $D$. microps has no effect on the numbers of P. longimembris or D. merriami. The removal of P. longimembris has no measurable effect on the numbers of $D$. merriami or D. microps.

While the number of $P$. longimembris on a grid in-reases in response to the removal of $D$. merriami as predicted, our analysis indicates that an average of $13 \mathrm{D}$. merriami have to be removed for an increase of one $P$. longimembris. This response is about 13 times weaker than the reaction of Perognathus to removal of Dipodomys in the Chihuahuan desert (Lemen and Freeman 1983). Moreover, in the second year no response by $P$. longimembris to the removal of $D$. merriami could be demonstrated. The lack of response may have reflected some density dependence of interference competition such that at low densities interference competition may not be present. However, in the second year the low numbers of $D$. merriami on the grids would have made it difficult to quantify a reaction. With an average of $14.6 \mathrm{D}$. merriami per removal grid there is only an expected average response of 1.13 P. longimembris (based on the results on the first year). Such minor changes are difficult to detect statistically with the sample sizes of grids used in this study. They may or may not have been present.

Our initial goal was to determine if there are shortterm responses to the removal of species from a heteromyid community. Several lines of evidence suggest that such a reaction is possible. First, other studies of similar species have found such short-term reactions. Second, the general ecologies of these rodents, especially D. merria$m i$ and $P$. longimembris, indicate at great deal of overlap in food habits and habitat preferences. Our analysis indicated that short term responses were weak in the community we studied for two summers.

Therefore, our results are at odds with the strong inerference competition found in heteromyids by Lemen and Freeman (1983) and Frye (1983). However, our results are also inconsistent with Schroder and Rosenzweig (1975) and Munger and Brown (1981) who found no fast response to removals in heteromyids. It is not ob- vious why the last studies were not able to find short-term responses to removals. This is particularly true for the study by Munger and Brown (1981) who, like us, worked with a small Perognathus and a mid-sized Dipodomys. It is possible the importance of interference competition may vary from place to place or from year to year. Certainly, the density of the rodents do vary greatly through time. Another factor that might have caused a difference in our results is the use of fenced grids by Munger and Brown (1981). While their grids did allow passage of Perognathus at sixteen points, this might not have provided sufficient movement and contact for the interference competition to have an effect. Further, because the interference competition we documented was relatively weak, the smaller grids and fewer animals used by Munger and Brown (1981) might not have been able to quantify this weak interaction.

Acknowledgements - We thank the Field Museum of Natural History, Chicago, for the initial support for this project; the University of Nebraska-Lincoln for support in the second year; the Nevada Department of Wildlife and the Bureau of Land Management for their cooperation; M. Clausen and J. Krupa for their tireless assistance in the field; G. Littrell for typing the manuscript, and M. Marcuson for preparing the graphs.

\section{References}

Abramsky, Z. and Sellah, C. 1982. Competition and the role of habitat selection in Gerbillus allenbyi and Meriones tristrami: a removal experiment. — Ecology 63: 12421247.

Blaustein, A. R. and Risser, A. C. 1974. Dominance relationship of the dark kangaroo mouse (Microdipodops megacephalus) and the little pocket mouse (Perognathus longimembris) in captivity. - Great Basin Nat. 34: 312316.

— and Risser, A. C. 1976. Interspecific interactions between three sympatric species of kangaroo rats (Dipodomys). Anim. Behav. 34: 381-385.

Bowers, M. A. and Brown, J. H. 1982. Body size and coexistence in desert rodents: chance or community structure. — Ecology 63: 391-400.

Brown, J. H. 1971. Mechanisms of competitive exclusion between two species of chipmunks. - Ecology 52: 305311.

1975. Geographical ecology of desert rodents. - In: Cody, M. L. and Diamond, J. M. (eds), Ecology and evolution of communities. Belknap Press, Cambridge, MA, pp. 315-341.

Cameron, G. N. 1971. Niche overlap and competion in woodrats. - J. Mamm. 52: 288-296.

Congdon, J. 1974. Effects of habitat quality on distribution of three sympatric species of desert rodents. - J. Mamm. 55: 659-662.

Cronquist, A., Holmgren, A. H. and Revel, J. L. 1972. Inter-mountain flora: Vascular plants of the Intermountain West. Vol. I. - Hafner, New York, NY. 
Eisenberg, J. F. 1963. The behavior of heteromyid rodents. Univ. Calif. Publ. Zool. 69: 1-100.

Fleming, T. 1974. Social organization in two species of Costa Rican heteromyid rodents. - J. Mamm. 55: 543-561.

Frye, R. J. 1983. Experimental field evidence of interspecific aggression between two species of kangaroo rat (Dipodomys). — Oecologica (Berl.) 59: 74-78.

Goodnight, J. H., Sail, J. P. and Sarie, W. S. 1982. GLM. - In: SAS User's Guide: Statistics. SAS Inst. Inc., Cary, NC, pp. 139-204.

Grant, P. R. 1972. Interspecific competition among rodents. Ann. Rev. Ecol. Syst. 3: 79-106.

Hutto, R. L. 1978. A mechanism for resource allocation among sympatric heteromyid rodent species. - Oecologica (Berl.) 33: 115-126.

Kotler, B. P. 1984. Risk of predation and the structure of desert rodent communities. - Ecology 65: 689-701.

Lemen, C. A. 1978. Seed size selection in heteromyids. Oecologia (Berl.) 35: 1201-1219.

— and Freeman, P. W. 1983. Quantification of competition among coexisting heteromyids in the Southwest. Southw. Nat. 28: 41-46.

Munger, J. C. and Brown, J. H. 1981. Competition in desert rodents: an experiment with semipermeable exclosures. - Science 211: 510-512.

OTarrell, M. J. 1980. Spatial relationships of rodents in a sagebrush community. - J. Mamm. 61: 589-605.

Price, M. V. 1983. Ecological consequences of body size: a model for patch choice in desert rodents. - Oecologia (Berl.) 59: 384-392.

1984. Microhabitat use in desert rodent communities: predator avoidance or foraging economics? - Neth. J. Zool. 34: 63-80.
Rebar, C. and Conley, W. 1983. Interactions in microhabitat use between Dipodomys ordii and Onychomys leucogaster. - Ecology 64: 984-988.

Reichman, O. J. 1981. Factors influencing foraging patterns in desert rodents. - In: Kamil, A. and Sargent, T. (eds), Mechanisms of optimal foraging. Garland Press, New York, pp. 195-213.

— and Oberstein, D. 1977. Selection of seed distribution types by Dipodomys merriami and Perognathus amplus. -Ecology 58: 636-643.

Rosenzweig, M. L. and Winakur, J. 1969. Population ecology of desert rodent communities: habitats and environmental complexity. - Ecology 50: 558-572.

Schroder, G. E. and Rosenzweig, M. L. 1975. Perturbation analysis of competition and overlap in habitat utilization between Dipodomys ordii and D. merriami. - Oecologica (Berl.) 19: 9-28.

Schroder, G. D. and Geluso, K. N. 1975. Spatial distribution of Dipodomys spectabilis mounds. - J. Mamm. 56: 363367.

Small, R. J. and Verts, B. J. 1983. Responses of a population of Perognathus parvus to removal trapping. - J. Mamm. 64: 139-143.

Smigel, D. W. and Rosenzweig, M. L. 1974. Seed selection in Dipodomys merriami and Perognathus penicillatus. Ecology 55: 329-339.

Stamp, N. E. and Ohmart, R. D. 1978. Resource utilization by desert rodents in the Lower Sonoran Desert. - Ecology 59: 700-707.

White, E. G. 1971. A versatile Fortran computer program for the capture-recapture stochastic model of G. M. Jolly. Fish. Res. Bd Can. 28: 443-445. 